\title{
Digital Transformation of Agencies for Students` Part Time Jobs in the Republic of Croatia
}

\author{
Sonja Nidogon Višnjić \\ Faculty of Organization and Informatics \\ University of Zagreb, Varaždin, Croatia \\ Neven Vrček \\ Faculty of Organization and Informatics \\ University of Zagreb, Varaždin, Croatia
}

svisnjic@foi.hr

nvrcek@foi.unizg.hr

\begin{abstract}
Digital transformation (DT) of agencies for students part time jobs in the Republic of Croatia (RC) began to be mentioned through the adoption of the Act of student activities (Act). The work of students in the Republic of Croatia is regulated by the Act [1], which provides the legal basis for the DT system of mediation in employment. The Act and the Ordinance oblige the mediator to keep all records in electronic form and define the possibility of issuing student contracts in electronic form, but up to now this form of contract has not been experienced in practice [1], [2]. The distinction between digitization and DT in part led to the fact that the electronic student contract currently implies the issuance of an online student contract, which was not signed by an advanced electronic signature. Changes in business caused by COVID-19 contributed to greater utilization of existing online contracts and pointed to inconsistencies in the work of intermediaries. The aim of this paper is to present, based on a literature review and analysis of the existing situation through the case study, the conceptual model of the DT system for mediation in employment and to test the digital maturity of the current system. The scientific contribution of the paper is in presenting a model that can be implemented in the daily practice of all students employment agencies, while the social contribution is reflected in the attempts of DT public institutions that should be used as an example to the private sector.
\end{abstract}

Kewyords: digital transformation, digitalisation, agencies for students` part time jobs

\section{Introduction}

Digital transformation (DT) is a term that is increasingly present in the everyday life and work of every individual, whether it is a private or business sphere of life, it is a long-term process, which will never be comprehensive and complete, precisely because DT implies continuous adjustment to new digital tools and technological innovations. Digital transformation must be applied to both business processes and human resources in order to be successfully applied and implemented, with the aim of bringing digital technology closer to users in the best possible way, to obtain the 
information and services they want, how an when they want them. Since each individual is an individual for himself, so each business organisation or public institution is specific, so there can be no single DT that will absolutely be the same for all business entities.

The European Commission's (EC) programme, Digital Europe, represents a multiannual financial framework for the period between 2021-2027, in order to ensure a quality instrument, adapted to all and represents a comprehensive response from the EC to the complexity of the DT process. The programme aims to provide funds for the targeted digital transformation of Europe's society and economy, covers five priority areas DT: supercomputing, artificial intelligence, cyber security and trust, advanced digital skills and ensuring the widespread use of digital technologies throughout the economy and society as a whole. According to the EU analysis, DESI of the Digital economy and Society Index in Croatia for 2019 the Republic of Croatia (RH) was only the 21 st out of 29 EU member States. When considering category DT, integration of digital technology within business entities, the Republic of Croatia ranked the 18 th, while in the category of digitisation of public services it ranks the 22 nd [3], [4].

Student work in RC represents a special category of employment and is enabled through the mediation of student services, as institutions that act as separate components within universities and polytechnics and are authorized to mediate in temporary and occasional work of students. The work of students in the Republic of Croatia is regulated by the Act [1], which provides the legal basis for the DT system of mediation in employment. This paper represents a conceptual framework for DT services of mediation in student employment, created as a result of a systematic review of literature and analysis of case studies. After the introduction, we follow the chapter that explains the materials and methods used and the motive and goal of the research itself. After that, the paper presents the results of the literature review through individual research methodologies of the degree of DT, explains the very concept of DT and DT of public administration, and an example of the case study itself and the conclusion.

\section{Material and methods}

The Web of Science platform was used as the starting point for the systematic review of literature. The keywords used in the search were: "digital transformation, at the title level, in the last 5 calendar years, in the management category. The test resulted in 200 papers (on 24 Jan 2021) and was additionally narrowed down to 47 open access works. The content was extrapolated on the basis of thematic content, the basic inclusion and exclusion criterion was the very topic of scientific work and research area [5]. After collecting and analysing the papers, synthesis [6] results of qualitative research were made and the empirical part was presented, the case study was presented as a proposal of the model DT system for mediating student services, agencies for students ' part time jobs in the Republic of Croatia. This case study was made on the basis of an analysis of the existing system and years of experience in working with the same author of the paper. 
Literature review and systematisation is the starting feature of every scientific paper because it facilitates the development of theoretical knowledge, indicates areas of high relevance and offers guidelines for future research [7] [8]. Case studies help in analysing existing situations and predicting future trends, in order to understand the research issue more clearly, they use qualitative, quantitative or mixed research methods [20], [21].

\subsection{Motives and the aim of research}

The author's motivation is to know the existing system of mediation employing students and to point out the need of DT and to adapt the system to new market requirements and modernisation of operations. The aim of this paper is to raise the quality of mediation services, i.e. to answer the question of whether there is a real need for student services (agencies for students' part time jobs) in the Republic of Croatia? The purpose of the paper was to present the case study, but before the case study itself, the literature had to be examined, with the aim of creating a framework of research with regard to comprehensive, non-harmonised and varied literature that includes DT terms. In order to achieve the aim of the research, a theoretical model will be defined based on literature review, and a DT model proposal will be developed for the purpose of presenting the case study.

\section{Individual research methodologies, individual methods and tools used to investigate the degree of digital transformation and maturity}

To achieve the digital competitiveness, it is first necessary to identify the degree of DT and maturity of an individual business entity. A review of the literature led to some methodologies that detect the degree of digital transformation. Conceptual frameworks for DT and business model innovation (BMI innovation), help to see the broader picture and provide answers to questions about digitalisation, DT and business models and what similarities exist between them [11].

Enterprise's business strategy should ensure that digital transformation is put in the forefront, but without investment in capabilities and human resources, the upgrading of digital skills, knowledge and capabilities cannot provide DT [11], [9], [10]. Business model CANVAS BMC consists of nine basic, interconnected, dependent elements that visualise processes in the enterprise: key partners, key activities, key resources, value proposals, customer relations, channels, customer segments, cost structure and revenues. The idea is that each element of the BMC gives its view, which does not necessarily have to be related to other elements, each element has its specific characteristics [8] [9].

The business model presented by P. Gomber to better understand fintech innovation is based on the key elements of several previous frameworks to give a clearer picture of innovation and financial services over the past few years. 


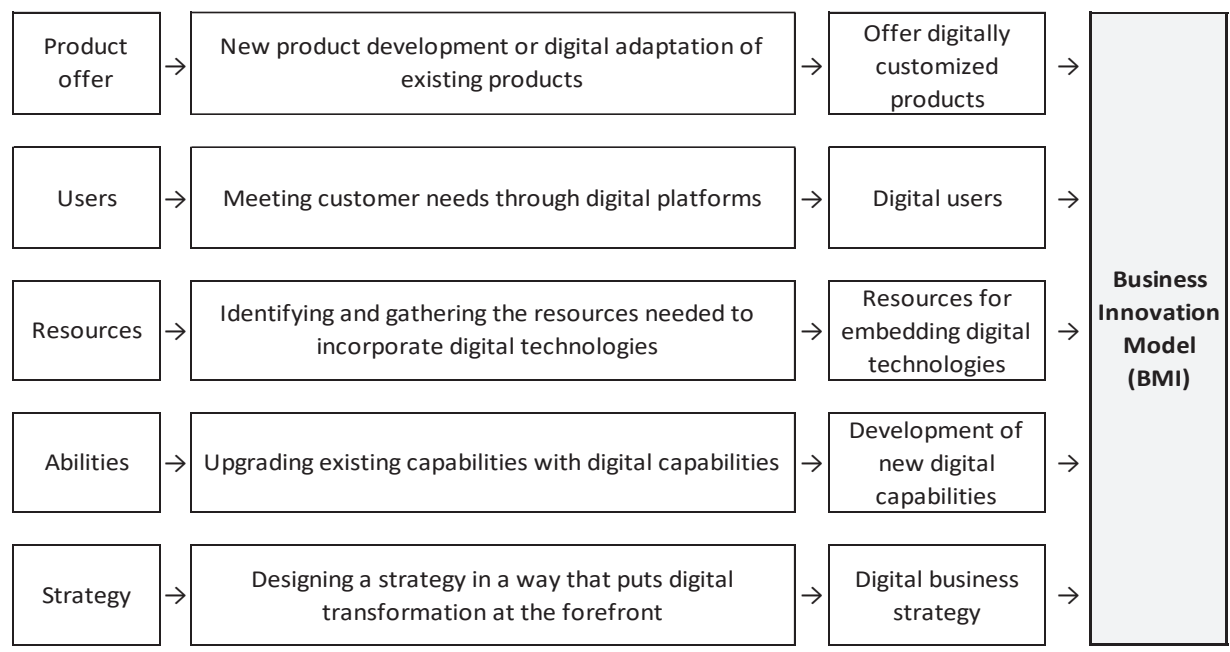

Figure 1. Conceptual framework for digital transformation of business model elements, according to C. Tonder [7]

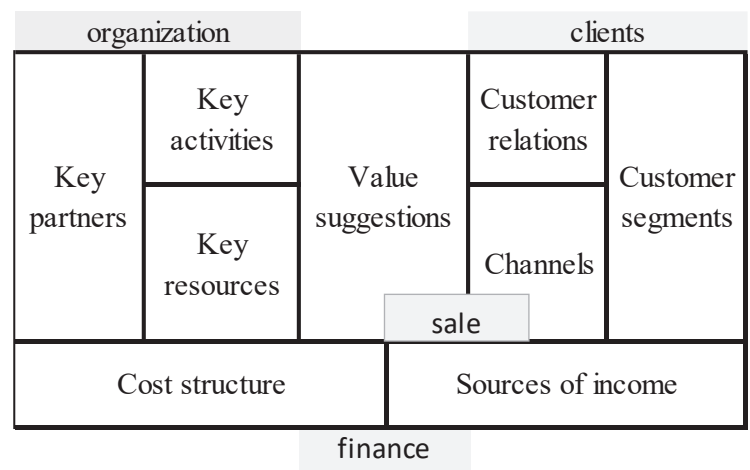

Figure 2. Basic elements of the BMC, according to Osterwalder [8]

The business of financial services always includes a large number of different users, repeated service interactions and the use of state-of-the-art technological developments, and new fintech approaches create new reductions in human involvement on purely transactional aspects, supported by machine intelligence, and human involvement when providing added value to the product or services [10]. Relying on theoretical perspectives, Fredrickson's theory of expansion and construction (2001) and the theory of preserving resources (Hobfoll, 1989, 2001), P. Malik and P. Garg point out that the learning organisation can prove to be an important driver for encouraging positive feelings among employees [11]. Through the Global Bank project, a group of authors studied its impact on organisational changes through the idea of a broken balance [12]. The analysis of digital reporting using XBRL (extensible business reporting language) technology, with the aim of digitising traditional reports according to the governing structures, has shown that digital business reporting has significant implications on the rationalisation of business methods in the general administration [13]. 


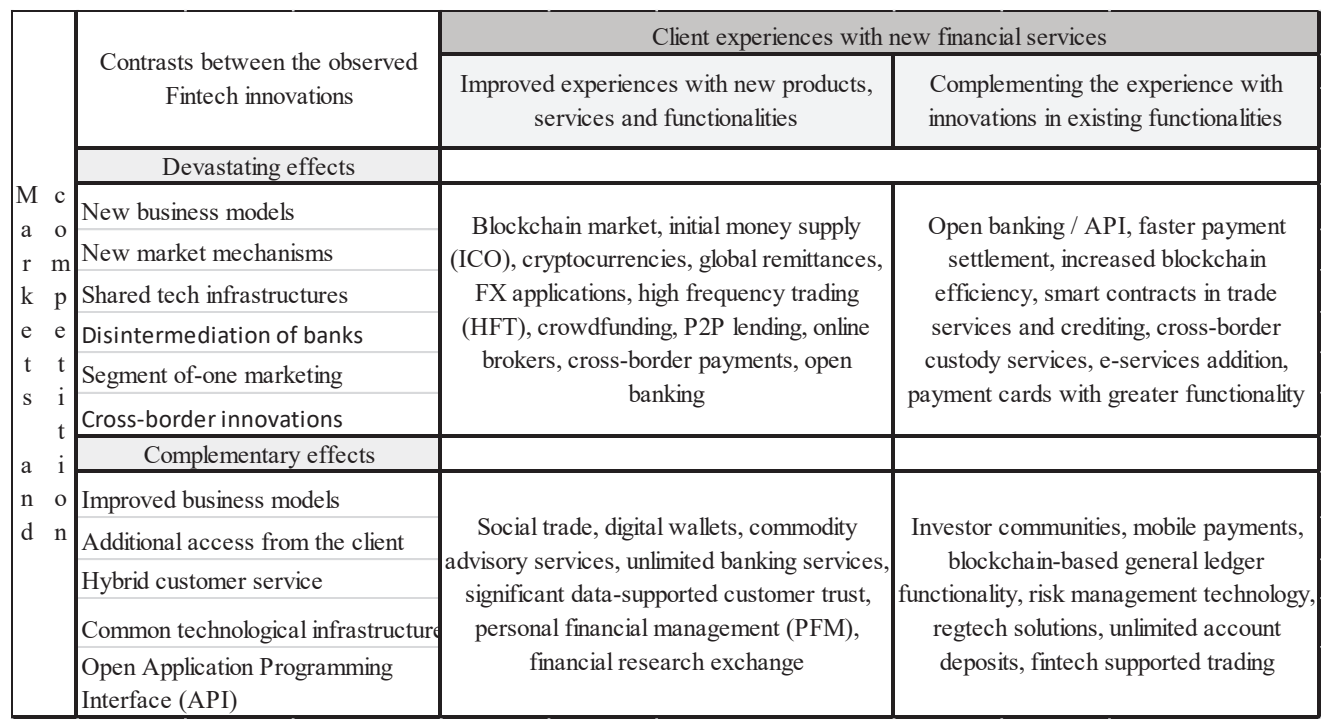

Figure 3. Fintech innovation review from the point of view: market-competition-customer experience, according to Gomber [10]

SWOT analysis (strengths - weaknesses - opportunities - threats), in a simple but sometimes subjective way, gives an overview of internal strengths and weaknesses and external circumstances and threats, is based on the assumption that the basis of any successful strategy, the exploitation of existing strengths and opportunities, and the minimisation of expected weaknesses and threats [14] [15].

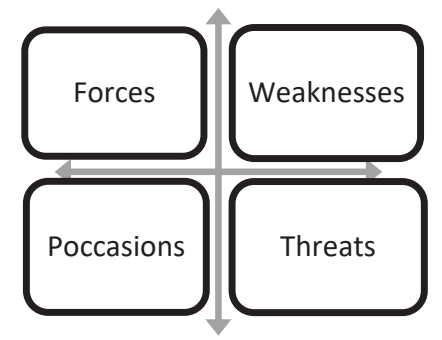

Figure 4. SWOT analysis model according to A. S. Humphrey

The interpretative framework created on the basis of the case study of the international employers shows one of the ways of the DT implementing in order to achieve international competitiveness through the idea offering opportunities for combining and strengthening tradition and innovation, both local and global ones[16].

Apsolon, a regional company based on the collected data from 300 large and medium-sized Croatian companies through the research company, has developed a tool that serves to evaluate or self-evaluate the digital transformation of companies, known as the Croatian Digital Index (HDI) [17]. 


\subsection{The concept of digital transformation}

There is no universally accepted definition of digital transformation that would comprehensively define all areas and all transformations that digital transformation (DT) covers. DT also implies that "fundamental new capabilities are created in the business, public administration and in the life of people and society, while digitalisation represents only a 'transition to online business, i.e. the transition from analogue to digital business, but without any changes in kind in the process itself' [18] [19]. The goal of the DT is to create new values and new opportunities in the future, not simple technological changes that merely try to overcome business shortcomings and correct historical errors. The DT business models include 'networking of all actors in all segments of the value-added chain, application of new technologies, DT requires skills that include both finding and exchanging data, as well as the analysis and conversion of these data into concrete information, in order to increase the success and progress of the company. DT includes enterprises, business models, processes, relationships, products, etc. '[20], [7]. These are organisational changes that condition the application and dissemination of digital technology from four different perspectives, namely: technological impact, fragmented adaptations, systematic changes and perspectives and holistic evolution, and DT can be best understood as a continuous change that can be activated and shaped by occasional outbursts, while each incident stimulates a further course of continuous changes [21], the way of modifying and adapting business models, resulting from the dynamic pace of technological advancement and innovation that trigger changes in both social and consumer behaviour [9]. Philosophical approaches view DT as the reflex ability to think differently about a problem in order to identify constraints and provide practical reasoning and challenges of DT society force us to look at a broader picture outside our comfort zone [22]. The term DT implies the combined effects of several different digital innovations that necessarily bring with it new actors, structures, practices, values and measurements that change or complement existing rules within the organisation while implementation requires substantial changes in the business model that typically arise as a result of evaluation of some previous concepts due to technological advancement or innovation. DT implementation platforms are typically enabled through basic technologies such as the Internet, but also social aspects such as networking and social networks. By copying DT to the business model canvas (BMC), it eases the assessment of digital maturity [22], [9], [23].

Digital transformation strategy (DTS) by itself does not constitute a break with the conventions of any pre-planned IS strategy, but only the need to develop a new strategy, since DTS is a very dynamic process that implies the continuous exchange of learning and work cycles [24]. DT transforms both innovation and entrepreneurship, digital technologies not only open up great opportunities for innovators and entrepreneurs, but indirectly affect the increase in value, affects the working habits and health of each individual, contributes to greater use of information and communication technology (ICT), affects performance and management of talents, but also the organisational hierarchy, carries openness, availability and generalisation of information. The conceptual platform enables the connection of problems between different levels, as well as the integration of ideas from different 
fields and disciplines [25] [26]. Global standards regarding open science contribute to faster innovation and public services [27]. DT of financial services takes place in four different areas: management of financial services, technological innovation, cryptocurrency, blockchain and cross-border payments [10]. Chanias and associates represent a DT model consisting of 6 phases through change of strategy from the bottom up. Depending on the planned scope of digitisation, the focus level of the business model [24] is also selected [28]. Investments in human resources in order to maintain competitive advantage are inevitable, while at the same time there are certain resistance, organizations that cultivate continuous learning and adaptation to DT have a positive effect on overcoming employee resistance and increasing work engagement, employees who are strongly opposed to DT because they believe in their abilities are even more trying and employing to prove this. It is not enough to focus only on increasing the skills and knowledge of human capital, but also on developing the psychological forces of human resources, it is necessary to invest in learning organisations [11].

In $\mathrm{RC}$, the term DT is still more connected with digital than with the development of new digital models. Despite the optimism of respondents is noticeable when evaluating the state of digitalisation of the Croatian economy as a whole when evaluating the evaluations from the previous period, no significant deviation was observed in responses between large and medium-sized enterprises [17].

\subsection{Digital transformation of public administration}

Accepted digital technology and information technology (IT) in everyday life of an individual also leads to different convictions of individuals towards IT technology, and these convictions in the long run change employee activities related to it, resulting in a mismatch in IT management. Three basic dimensions of IT management are highlighted: focus, scope and patterns, while the use of IT in the workplace depends greatly on the perception of the user, i.e. employees transfer their personal convictions and experience in working with digital technology in the workplace [12]. The DT of traditional forms of reporting reduces the administrative burden of business entities, but is largely hampered by different laws and regulations of institutional bodies. A group of authors, using a comparative approach to analyse qualitative data from three different countries, which were at the international level leading in transformations between businesses and governments, came to the conclusion that the development of digital reporting is greatly influenced by both international and local factors of each country and every enterprise. Those actors who initially did not consider DT a necessity were nevertheless involved in the processes in response to the concessions offered by the regulatory authorities rather than reacting with proactive action. The government regulators in all the surveyed countries initially had to ensure the availability of effective applications before they could and required the use of digital reporting [13]. The key factors needed in the DT of the public administration are anticipating leadership and investment in human resources. An appropriate strategic choice for the transformation of the public administration is a digital strategy, which 
focuses on operational efficiency with user data and on improving the tools for cooperation and exchange of views [29].

The Strategy e-Croatia 2020 is a strategic framework for DT of public services in line with the EU directives which should ensure functionality and interoperability between existing and new ICT systems in the public administration. The interoperability system is not yet functional although it should ensure that all public information systems are connected on the principle of silo into a single system, thus enabling the legal, organisational, technical and all other barriers to be bridged so that all public services and other services can exchange unique information [15]. In RC, the state and society as a whole have a great influence on the DT business sector. The measures required under the HDI for 2020 are the digitalisation of administration (eservices for citizens and legal entities, shared service centres; education digitalisation and the broadband internet [17]. Positive developments are visible. We are dealing with the availability of new e-services for citizens and business entities, we are dealing with the development of new school curricula that contain the essential determinants of digital transformation of education, and the Ministry of sea, transport and infrastructure has launched a Strategy for the broadband internet development. In spite of that regulatory framework and learned behaviour and policies of public institutions are hampering faster implementation of DT public administration in the Republic of Croatia. Smart cities represent a local government issue because it should ensure a better quality and more satisfied life for its citizens, but a targeted focus on citizens needs is lacking. Most initiatives related to studies of cases of smart cities are still in successful stages of planning, but since these are long-term processes it is necessary to present key stages of progress openly and regularly, the lack of focus on end users, consumers, citizens is highlighted, because there are no measurable indicators of quality of life. Smart cities are present, but in the future these goods and services should focus on the expectations of the citizens themselves [30].

\subsection{Guidelines for digital transformation}

With its programmes, the European Commission encourages targeted DT of the economy and society as a whole, the digitalisation of business systems is to a lesser or greater extent already present in all business spheres and private lives of individuals, but should also be an integral part of public policy of governments and States. It is also necessary to connect public and non-profit organizations with all other stakeholders on the market, that is, the connection between public policy and economists and the adjustment of all business models towards the end user of our service, towards the customer of our services, towards the citizens if we look from the point of view of the public administration. It is necessary to strengthen the psychological side of the individual, educate the employees and overcome resistance to change, since in human nature, there is a fear of new and unknown, but by educating employees and continuously investing in the organizations they learn, all benefits of DT business are considered in human capital [9] [11].

World Digital Competitiveness scale World digital Competitiveness ranking IMD) on the global level shows progress, it is formed based on research of important 
DT factors and determinants: knowledge factor, technology factor and readiness factor for the future. The leading position is the USA, Singapore and Sweden, while the Republic of Croatia ranks 52 , which is one place down from the previous year in the total of 63 countries [31]. The digital gap between the EU Member States, which also affects the social and economic progress of the EU as a whole, is linked to the dimensions of national intellectual capital (NIK), and is largely reflected in social capital, knowledge and education and working skills as dimensions of human capital [32].

Looking at DESI index $2020 \mathrm{RH}$ ranks 20 th among the 28 EU members in the category of less successful countries. There is no progress compared to the previous year, and it is the weakest results in terms of connectivity and digital public services, which indicates that it is not sufficient to convert individual analogue forms only into digital ones, but that a complete DT of all processes is necessary [4]. The index of digital transformation of the Croatian economy shows that finances, existing business priorities and lack of time to focus DT are the main obstacles that hamper business people in DT, but also that changing the overall corporate governance culture is essential for the success of DT [17]. Without broadband internet and without DT of the entire public administration in the $\mathrm{RC}$, it is not possible to achieve more visible economic growth and progress. Linking Osterwalder's canvas to the business model and R. W. Gregory research, it can be said that the adoption of new patterns of behaviour as a precondition for digital transformation of business processes depends greatly on the perception of the user himself, i.e. that the employee also transfers his personal convictions and experience in working with digital technology to the workplace, and that in this case the approach towards the end user [9] is also applied [12].

Crisis situations force both businessmen and public institutions and governments of States to accelerate the adaptation of their business to new imposed conditions, COVID crisis in a way has forced many public institutions to turn to e-ways of doing business, online education and online teaching have become common ways of education overnight. Many are only now seeing the advantages of such an approach. Unfortunately, the mere digitalisation of certain segments of public services will not yield the expected results in the long if it is not based on the DT of the entire system. According to the recommendations of the European Commission, DESI and the conclusions of Apsolon, a comprehensive curriculum is necessary in RC and its complete and systematic implementation at the national level and investments in the development of ICT experts in order to make use of all available resources offered by the digital economy. The development of new and revised study programmes at Varazdin's Faculty of Organization and Informatics, which are harmonised with the needs of the demanding digital market, is also on the sidelines of these guidelines [4], [17], [33].

Digital platforms for new ideas, technologies and knowledge transfer are drivers and catalysts of the digital transformation of a particular enterprise and society as a whole, because knowledge exchanged and upgraded through digital platforms implies a high degree of interaction between participants, both internally and externally [34]. The human-dominated national intellectual capital has a statistically significant 
impact on the country's economic growth rate, significant differences have been identified between the EU Member States regarding NIC and there is a clear division between the north and south of the EU, while the largest resources are intellectual capital in the countries of Northern Europe [32]. Iti s necessary to adjust public services to both economists and citizens, so that DT can live in practice, as well as to change the entire mental structure of public institutions and accompanying services. The public sector needs to turn to its users, open up and adapt to the digital time in which we live and be the main driver and promoter of changes in society and economy, DT in the private sector cannot be complete without interaction with citizens and the public sector.

\section{Digital transformation of student services - agencies for students' part time jobs in the Republic of Croatia, the example of case studies}

The purpose of public institutions of student services - agencies for students` part time jobs in the Republic of Croatia is to be an adequate service to their users, that is, students and business subjects who use the services of occasional and temporary student work. Today we can talk only about digitization of these services, although some agencies for students' part time jobs are working fast on the DT of their systems. The crisis caused by COVID-19 prompted the accelerated digitalisation of public administration services and public institutions, thus showing that even relatively three systems of public institutions can be digitised successfully. DT public student services - agencies for students' part time jobs should bring basic new business processes or redesign of the existing ones, conditions and strategies for the implementation of long-awaited and necessary, justified digitisation projects in a way that will contribute to the digital maturity of the system in the long run. Current digital solutions involving the issuance of online student contracts in electronic form may indicate that the system is to a certain extent digitised but not that it is indeed a DT system [9]. The work of students in the Republic of Croatia is regulated by the Act [1], and until its adoption [35], the Directive of regular student employment was in force in 1996 [5]. Student centres act as other components within universities and polytechnics and are also authorised to mediate in the part time jobs of students [6].

Until the adoption of the Act, which formally regulated the possibility of electronic student contract, the student centre Rijeka has had the possibility of issuing an online contract since 2008, and the student centre Varazdin since 2017, and by adopting the Act the electronic contract became a legal obligation of all mediators (all agencies for students ' part time jobs). For the purpose of work, it is also necessary to distinguish the concept of an electronic contract defined by the Act from the current possibility of the online issuance of a student contract. For the full application of the electronic student contract, all legal requirements have not been fulfilled yet, i.e. all participants in the tripartite relationship should also have advanced electronic signatures, which is not the case in practice. Although online contracts were expected to completely suppress the issuance of forms at the physical location of intermediaries, this did not happen, and COVID-19 pandemic prompted most of the working-hired students and employers to turn to online issuance of contracts. The survey showed 
that employers used the online contract issuing system only to a lesser extent, $60 \%$ of them used the system from the date of application of the Act, while $10 \%$ of employers accepted the possibility of online contract issuance only with the appearance of the virus corona. Students were slightly better acquainted with the possibilities of online contract issuance, so $19.73 \%$ said they had been using the system for years, $47.37 \%$ began using online contracts after the application of the new law, while $27.63 \%$ sought an alternative to issuing contracts at physical locations only COVID 19. According to the available data from mediators, it is necessary for a longer period of time to root out old habits and for users to accept more modern ways of doing business [36].

\begin{tabular}{|l|r|r|r|r|}
\hline \multicolumn{5}{|c|}{ Participation in online student contracts } \\
\hline & \multicolumn{1}{|c|}{ Rijeka } & Varaždin & Osijek & Zagreb \\
\hline 2015. & $26,65 \%$ & & & \\
\hline 2016. & $28,68 \%$ & & & \\
\hline 2017. & $32,08 \%$ & $2,37 \%$ & & \\
\hline 2018. & $34,95 \%$ & $12,63 \%$ & & \\
\hline 2019. & $32,12 \%$ & $15,71 \%$ & $18,60 \%$ & \\
\hline 2020. & $51,53 \%$ & $35,49 \%$ & $50,98 \%$ & $67,00 \%$ \\
\hline
\end{tabular}

Table 1. Participation of online student agreements concluded online from 2015 to 2020 in individual student services in the RC

It is currently possible to speak exclusively about digitization of this system and it is necessary to present a model of the complete DT mediation system of agencies for students` part time jobs.

\subsection{Conceptual framework of DT student services - agencies for students` part time jobs}

According to the Act, the mediators, in this case they are among agencies who mediate between students and employers and are obliged to keep all electronic databases. The status of a student is proven by insight into electronic data evidences about the students in the Information system of high schools (ISVU) [35], while the contract can also be concluded in the electronic form.

As a public institution, the first amendments to the legal and regulatory framework should lay down the necessary preconditions, although in practice the model itself is relatively simple to implement. There are already building information systems in which the necessary e-databases exist, and the DT system could unify the intermediation of all student services - agencies for students' part time jobs in the Republic of Croatia, thus leading to greater transparency, simplicity, uniformity and cost reduction. 


\section{FORCES}

Existing legal framework

Existing available electronic database electronic systems

Possibility of financing academic education, raising the quality of life of the student population

Acquisition of work habits, responsible behavior towards work

Performing professional practice, gaining work experience

A system that enables employers to hire a quality workforce without employment, lower costs of hiring temporary workers

The legal framework enables the financing of cultural, sports, scientific and educational activities of students

\begin{tabular}{|l|}
\hline \multicolumn{1}{|c|}{ OCCASIONS } \\
\hline $\begin{array}{l}\text { Recognition of student work experience as meeting the } \\
\text { requirements for the required work experience when } \\
\text { entering employment }\end{array}$ \\
$\begin{array}{l}\text { Unification of the student labor market, strengthening of } \\
\text { competitive advantage, better market coverage }\end{array}$ \\
Reduction of costs and necessary resources on the part of \\
all participants in a tripartite contractual relationship \\
$\begin{array}{l}\text { Uniformity of the system, reduction of the possibility of } \\
\text { abuse }\end{array}$ \\
$\begin{array}{l}\text { An employment model that could be applied in a wider } \\
\text { region of countries that recognize the category of work } \\
\text { during academic education }\end{array}$ \\
\hline
\end{tabular}

\section{WEAKNESSES}

The system unnecessarily wastes the time of all parties to the tripartite contractual relationship and other financial resources

The legal framework does not provide for the possibility of electronic enrollment of students in the databases of users of student services

Public e-systems are not electronically connected, information on natural persons or legal entities is not consolidated, it is not interoperable

Electronic systems such as the REST API and the ISVU student rights database are dependent on data from higher education institutions

Insufficient awareness of the need for a DT system by the competent public institutions

Users who do not use the available advanced electronic signature

Necessary financial resources for investment in technology and human capital

\section{THREATS}

Neglect of academic obligations due to work during academic education, focus on education funding

Some users of student services (in the category of crafts, family farms and small entrepreneurs) would be less competitive, due to the lack of (non-use) of advanced electronic signatures

Protection of personal data, GDPR

Resistance of managers and employees in student services, fear of losing existing job positions within the existing system.

Abolition of the category of student work, due to the impact on the labor market

Figure 5. Overview of the situation through SWOT analysis of student services' - agencies for students` part time jobs operations

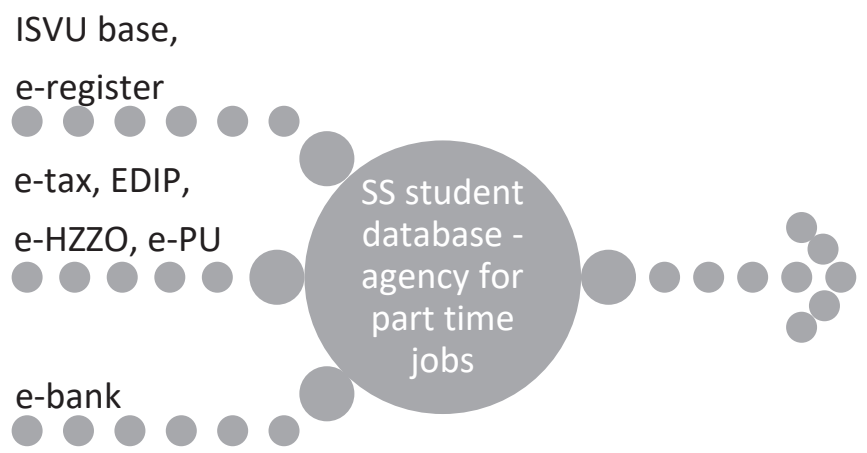

Figure 6. Basic model of student enrolment (part time job employees) into student service base - agencies for students` part time jobs 
The current student registration performs at the physical locations of student services as the mediator. As a result of COVID 19, there has been a slight shift, which could conditionally be considered as the digitisation of the system, under the notion of digitisation in this case only the sending of documents by email can be considered. There are all technical preconditions for DT of this part of the system: status of student or other person (high school graduate) can be electronically checked in the ISVU database (Information system of high schools in RC) and e-registers (centralised system of the Ministry of science and education that serves for all students' data input. The status of compulsory health insurance in the electronic HZZO database of insured people (Croatian administration of health insurance in RC). In the tax Administration e-database (unique portal of tax administration in $\mathrm{RC}$ ) it is possible to check whether the person is in employment and whether the owner of the craft or free occupation. In the Police Administration e-database (e-PU) the domicile or residence, while data on a business bank can be requested from the person who wants to join the student service system. In this way, all legal presumptions would be fulfilled, the possibility of possible manipulation and abuse of the system would be reduced, the system simplified and there is no need for the physical contacts.

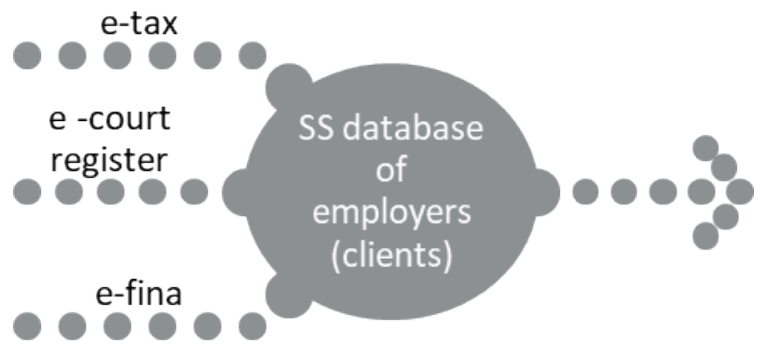

Figure 7. Basic model for the enrolment of employers (procuring entities) into the student service base - agencies for students' part time jobs

As regards employers (demanders of students' part time jobs), their registration in the user database can be done in a very simple way by linking the system from existing electronic databases: e-tax (tax Administration e-database), e-court registry and e-fina (Financial agency in the state ownership for giving financial and electronic services). Only an electronically signed employer's consent to allow access to data checks in existing registers would be sufficient. There is no need for physical contacts, the need to fill in printed form, authenticate them and send them by e-mail. An insight is gained into employers' business operations and the possibility of preventing business operations with employers who have blocked business accounts would be gained. The mediator - agencies for students ' part time jobs and student would also be protected, because the possibility of irrecoverable debts would be reduced to a much smaller extent.

Currently, the student employment contract is published (concluded) either at physical locations or through the individual student service - agencies for students part time jobs web interfaces in a conditionally stated electronic format. 


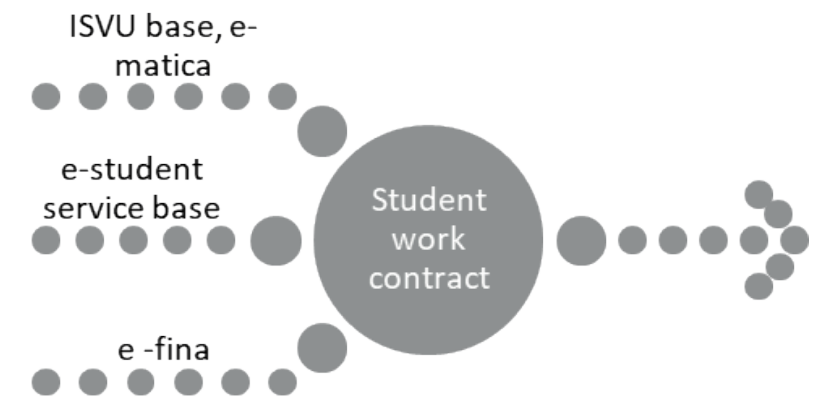

Figure 8. Basic model for the conclusion of the e- contract for the performance of student work

These contracts are only created online, at the service user's place, and they must be printed in a physical form, signed and stamped by all participants in a tripartite contractual relationship, and in a physical form and delivered to mediators - agencies. This online form of student contract is basically a novelty, since 12 student services authorised agencies for students ' part time jobs) of the currently registered 14 in the Republic of Croatia started to apply it only by force of the Law [1]. With the appearance of COVID-19 pandemic, this kind of contract prevailed and is currently being used to a greater extent from contracts concluded at the physical locations of mediators. For the contract to be truly electronic, a full DT system is required, i.e. all three sides of a triangular relationship (employers, intermediaries and students) should be users of an advanced electronic signature. The student center as the agencies for students' part time jobs and the client sign the document by qualified electronic signature (application certificate), while the student signs the document by advanced electronic signature.
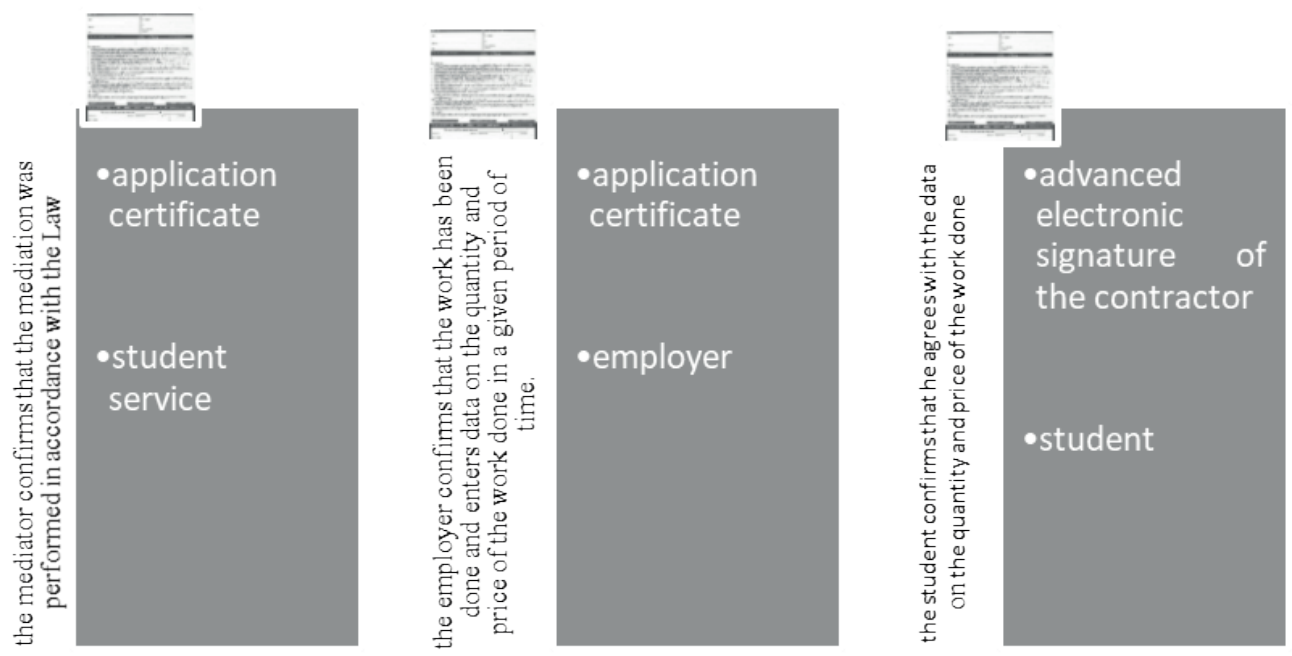

Figure 9. Basic model of prerequisites for issuing e-invoices based on e-contracts 
The contract signed in this way is purely digital, it is harder to misuse, the system would be more functional, practical, rational and cheaper. Such an electronic contract is a prerequisite and completely digitised, i.e. an electronic invoice and consequently an e-archive. The current contradiction of the existing system is that the e-invoice for performing student's part time jobs should be accompanied by a printed copy of the online student contract, which should also be physically verified by a stamp by the employer (contracting entity) and of course signed by the student in other words a part time employee.

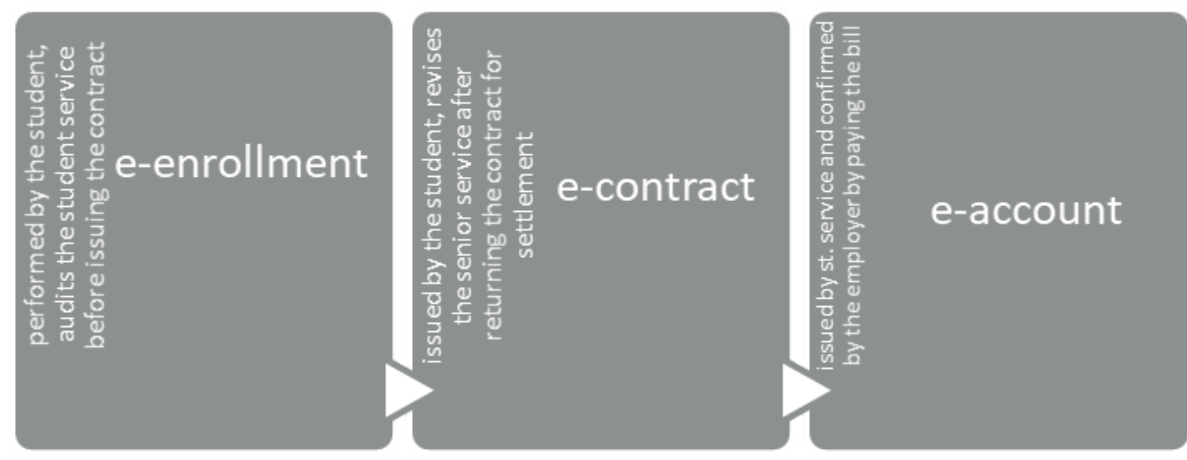

Figure 10. Basic model of digital transformation of the existing system

There is a legal framework, which, with slight changes and upgrades, can enable simple and very useful DT system of agencies for students part time jobs. Since all registered student centres in which student services (agencies for students` part time jobs in RH) also operate already have an existing information system, and 11 student services use almost identical software solutions for student enrolment and issuing student contracts and related accounts, DT of the existing system would provide a clear and complete picture of mediation in the part time jobs of students and other persons during their academic education.

\subsection{Assessment of digital maturity of student services - agencies for students part time jobs using BMC}

Analysis of the existing situation shows that agencies for students' part time jobs as public services that are responsible for performing employment mediation activities during academic and post-academic education of students do not fully follow the central interoperability system.

Through the application of Osterwalder's BMC on the example of agencies for students ' part time jobs, and according to the conclusions of Kotarba, conclusions are drawn [8], [9]:

- the updated strategy through the overall application of e-business digitally transforms the entire business, 


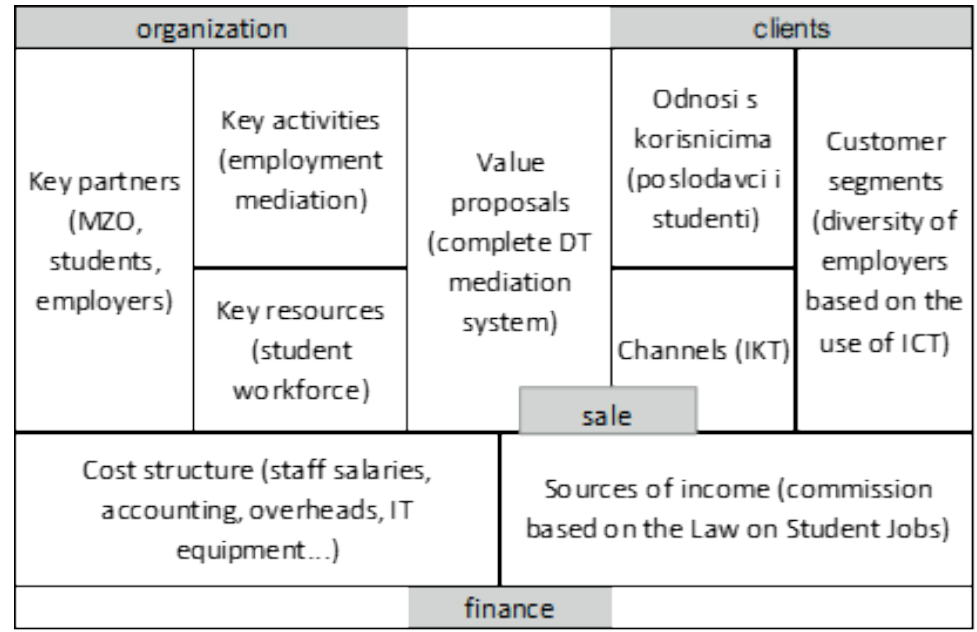

Figure 11. Basic elements of the salary model agencies for students` part time jobs, according to Osterwalder [6]

- the assessment of organisational business models leads to the conclusion that it is necessary to accept the news, make a distance from the usual way of doing business, modernize the existing system,

- changes in business models are the result of: application of the new Act and Ordinance, progress of ICT, harmonisation with client wishes and needs following technological advances, generation of economies of scale (equal opportunities for access to agencies for students` part time jobs to all users),

- all necessary platforms are provided through basic technologies, the internet, ecitizens systems and advanced electronic signatures, but also through social aspects (social networks such as Facebook and Instagram),

- $\quad$ BMC can be used as a reference point for the overall DT of all agencies for students` part time jobs in the Republic of Croatia.

Student services such agencies for students ' part time jobs are currently in the phase digitisation thanks to the application of online student contracts and the use of the REST API databases (program interface for access to data and procedures at higher education institutions in the Republic of Croatia), which uniquely defines the student status, it is necessary to harmonize the legal preconditions for targeted DT systems, adjust software packages, invest in technology, target marketing activities to educate users (employers and students) and employees who will work on the implementation itself. Starting point are clients, the emphasis is on how optimally adapt to both students and employers, respecting legal frameworks with targeted application of digital technology and assuming profit maximization. On one hand, we have employers, business buyers, from a wide range of activities and business scope. It is also necessary to adapt to small employers craftsmen who use student services, to be made available and flexible to them, as well as too large business partners and corporations, public institutions and establishments. Until the advanced electronic signature (application certificate) is the employer's legal obligation, the assumption is 
that smaller business partners will not use an advanced electronic signature, because at the moment they have a simpler and cheaper contract to sign and certify by physical signature. Students, agencies for students ` part time jobs users use advanced electronic signature to a very small extent, although they are provided with an e-ID card. Targeted DT and adjustment of the legal framework for all users of student services should make one option an advanced electronic signature (application certificate) of all participants in the tripartite mediation process and the other option would be the existing version of the online student agreement with scanned signatures of all participants in the process, without insisting on physical signatures and verification of the same documents and physical archiving of paper documents.

\section{Conclusion}

The digital transformation of the public administration still does not follow the DT of business entities, although public administration and public services should form the basis on which business entities should build the DT of their business processes [12]. The need for DT as a key driver of financial, economic and economic progress has also been recognised by the European Commission and, therefore, a multi-annual financial framework for Digital Europe has been created. Within the framework of its e-Strategy, the Republic of Croatia defines the DT plan which aims to ensure the functioning of the public administration within the framework of tomorrow. The operation of public institutions of student services - agencies for students ' part time jobs in the Republic of Croatia, acting as a component of universities and polytechnics requires DT in order to comply with the needs of modern business. Technical and legal presumptions exist, most of the necessary public e-services have already been developed, they only need to be combined, considering all aspects of data security and confidentiality. It is necessary to systematically invest in human resources while investing in ICT, for the DT system to be effective, a competitive advantage can only be maintained by investing in a resilient and engaged workforce, i.e. it is necessary to develop psychological forces of existing human resources [11]. The organisation that learns, which adapts to the transforming environment, always encounters resistance from employees and the environment in which it operates, but precisely these employee resistance stimulates employment and motivation of employees, it is sufficient that one agency for students' part time jobs goes to DT of the entire business, the potential resistance of the remaining thirteen registered agencies for students ' part time jobs will be broken, because the greater competitive advantage entails higher revenues. Although these are public institutions, the operations of agencies for students' part time jobs are financed from the basis of the mediation commission, so it is logical to expect that the economic nature of operations, the need to generate higher business revenues in order to cover operating costs and improve the student standard will also contribute to the DT system. The digitally transformed employment mediation system could be applied in other public services, higher education institutions and agencies providing employment mediation services. Restrictions on labour are reflected in the fact that they are public institutions that can base their business exclusively on legal regulations and procedures. The scientific 
contribution of the paper is presenting a model that can be implemented in the daily practice of all student employment agencies, while the social contribution is reflected in the attempts of DT public institutions that should be an example to the private sector.

\section{References}

[1] Narodne Novine, "Zakon o obavljanju studentskih poslova." https://narodne-novine.nn.hr/clanci/sluzbeni/2018_10_96_1851.html (accessed Apr. 22, 2020).

[2] "Pravilnik o obliku i sadržaju ugovora o obavljanju studentskih poslova." https://narodne-novine.nn.hr/clanci/sluzbeni/2019_01_3_64.html (accessed Nov. 03, 2020).

[3] Europska Komisija, "Izgradnja digitalne budućnosti Europe | Europska komisija.” https://ec.europa.eu/info/strategy/priorities-2019-2024/europefit-digital-age/shaping-europe-digital-future_hr (accessed Nov. 04, 2020).

[4] Europska Komisija, "The Digital Economy and Society Index (DESI)." https://ec.europa.eu/digital-single-market/en/digital-economy-and-societyindex-desi (accessed Nov. 04, 2020).

[5] Nacionalna sveučilišna knjižnica, "Portal elektroničkih izvora za hrvatsku akademsku i znanstvenu zajednicu." http://baze.nsk.hr/ (accessed Apr. 15, 2020).

[6] B. Kitchenham, and S. Charters, "Guidelines for performing Systematic Literature Reviews in Software Engineering," 2007, Accessed: Jan. 27, 2021. [Online]. Available:

https://citeseerx.ist.psu.edu/viewdoc/summary?doi=10.1.1.117.471.

[7] C. van Tonder, C. Schachtebeck, C. Nieuwenhuizen, and B. Bossink, "A framework for digital transformation and business model innovation," Management, vol. 25, no. 2, pp. 111-132, Dec. 2020, doi: 10.30924/mjcmi.25.2.6.

[8] P. Y. Osterwalder Alexander, (19) Business Model Generation: A Handbook for Visionaries, Game Changers, and Challengers | Request PDF. 2010.

[9] M. Kotarba, "Digital transformation of business models," Found. Manag., vol. 10, no. 1, pp. 123-142, 2018, doi: 10.2478/fman-2018-0011.

[10] P. Gomber, R. J. Kauffman, C. Parker, and B. W. Weber, "On the Fintech Revolution: Interpreting the Forces of Innovation, Disruption, and Transformation in Financial Services," J. Manag. Inf. Syst., vol. 35, no. 1, pp. 220-265, Jan. 2018, doi: 10.1080/07421222.2018.1440766.

[11] P. Malik and P. Garg, "Learning organization and work engagement: the 
mediating role of employee resilience," Int. J. Hum. Resour. Manag., vol. 31, no. 8, pp. 1071-1094, Apr. 2020, doi: 10.1080/09585192.2017.1396549.

[12] R. Wayne Gregory, E. Kaganer, O. Henfridsson, and T. Jean Ruch, "IT CONSUMERIZATION AND THE TRANSFORMATION OF IT GOVERNANCE Appendix A IT Governance Literature Review Table A1. Review of IT Governance Literature Study Definition of IT Governance Dimension of IT Governance," 2018.

[13] I. Troshani, M. Janssen, A. Lymer, and L. D. Parker, "Digital transformation of business-to-government reporting: An institutional work perspective," Int. J. Account. Inf. Syst., vol. 31, pp. 17-36, Dec. 2018, doi: 10.1016/j.accinf.2018.09.002.

[14] M. Gonan Božac, SWOT ANALYSIS AND TOWS MATRIXSIMILARITIES AND DIFFERENCES 2," Sveučilište Jurja Dobrile u Puli, Odjel za ekonomiju i turizam “Dr. Mijo Mirković," Mar. 2008.

[15] Ministarstvo uprave Republika Hrvatska, "STRATEGIJA e-HRVATSKA $2020, " 2017$.

[16] E. M. Martinelli, M. C. Farioli, and A. Tunisini, "New companies' DNA: the heritage of the past industrial revolutions in digital transformation," $J$. Manag. Gov., 2020, doi: 10.1007/s10997-020-09539-5.

[17] Apsolon d.o.o., “Apsolon-HDI-2020.-Digitalna-transformacija-uHrvatskoj-2020-1.pdf," 2020.

[18] "Definition of Digitization - Gartner Information Technology Glossary." https://www.gartner.com/en/information-technology/glossary/digitization (accessed Nov. 03, 2020).

[19] R. Gabryelczyk, "Has COVID-19 Accelerated Digital Transformation? Initial Lessons Learned for Public Administrations," Inf. Syst. Manag., 2020, doi: 10.1080/10580530.2020.1820633.

[20] D. Schallmo, C. A. Williams, and L. Boardman, "Digital transformation of business models-best practice, enablers, and roadmap," International Journal of Innovation Management, vol. 21, no. 8. World Scientific Publishing Co. Pte Ltd, p. 1740014, Dec. 01, 2017, doi: 10.1142/S136391961740014X.

[21] A. Hanelt, R. Bohnsack, D. Marz, and C. Antunes Marante, “A Systematic Review of the Literature on Digital Transformation: Insights and Implications for Strategy and Organizational Change," J. Manag. Stud., 2020, doi: 10.1111/joms.12639.

[22] F. Rowe, "Being critical is good, but better with philosophy! From digital transformation and values to the future of IS research," Eur. J. Inf. Syst., vol. 27, no. 3, pp. 380-393, May 2018, doi: 


\subsection{0/0960085X.2018.1471789.}

[23] B. Hinings, T. Gegenhuber, and R. Greenwood, "Digital innovation and transformation: An institutional perspective," Inf. Organ., vol. 28, no. 1, pp. 52-61, Mar. 2018, doi: 10.1016/j.infoandorg.2018.02.004.

[24] S. Chanias, M. D. Myers, and T. Hess, "Digital transformation strategy making in pre-digital organizations: The case of a financial services provider," J. Strateg. Inf. Syst., vol. 28, no. 1, pp. 17-33, Mar. 2019, doi: 10.1016/j.jsis.2018.11.003.

[25] S. Nambisan, M. Wright, and M. Feldman, "The digital transformation of innovation and entrepreneurship: Progress, challenges and key themes," Res. Policy, vol. 48, no. 8, Oct. 2019, doi: 10.1016/j.respol.2019.03.018.

[26] T. Schwarzmüller, P. Brosi, D. Duman, and I. M. Welpe, "How does the digital transformation affect organizations? Key themes of change in work design and leadership," Manag. Rev., vol. 29, no. 2, pp. 114-138, 2018, doi: 10.5771/0935-9915-2018-2-114.

[27] M. Bogers, H. Chesbrough, and C. Moedas, "Open innovation: Research, practices, and policies," Calif. Manage. Rev., vol. 60, no. 2, pp. 5-16, Feb. 2018, doi: 10.1177/0008125617745086.

[28] R. B. Bouncken, S. Kraus, and N. Roig-Tierno, "Knowledge- and innovation-based business models for future growth: digitalized business models and portfolio considerations," Rev. Manag. Sci., 2019, doi: 10.1007/s11846-019-00366-z.

[29] L. Kontić and Đ. Vidicki, "Strategy for digital organization: Testing a measurement tool for digital transformation," Strateg. Manag., vol. 23, no. 2, pp. 29-35, 2018, doi: 10.5937/straman1801029k.

[30] K. Tomičić-Pupek, I. Pihir, and M. T. Furjan, "Smart City initiatives in the context of digital transformation - scope, services and technologies," Manag., vol. 24, no. 1, pp. 39-54, 2019, doi: 10.30924/mjcmi.24.1.3.

[31] Institut za razvoj poslovnog upravljanja (IMD), "Institut za razvoj poslovnog upravljanja (IMD) iz Lausanne,” 2020. Accessed: Jan. 08, 2021. [Online]. Available: http://konkurentnost.hr/imd-svjetska-ljestvicadigitalne-konkurentnosti-2020/digitalna-konkurentnost-2020/.

[32] J. Švarc, J. Lažnjak, and M. Dabić, “The role of national intellectual capital in the digital transformation of EU countries. Another digital divide?," $J$. Intellect. Cap., 2020, doi: 10.1108/JIC-02-2020-0024.

[33] FOI, "FOI od jeseni izvodi revidirani studijski program 'Informacijski i poslovni sustavi' | FOI,” 2020. https://www.foi.unizg.hr/hr/novosti/foi-odjeseni-izvodi-revidirani-studijski-program-informacijski-i-poslovni-sustavi (accessed Jan. 15, 2021). 
[34] M. Hossain and A. Lassen, "Q\&A. How Do Digital Platforms for Ideas, Technologies, and Knowledge Transfer Act as Enablers for Digital Transformation?," Technol. Innov. Manag. Rev., vol. 7, no. 9, pp. 55-60, Sep. 2017, doi: 10.22215/timreview/1106.

[35] Sveučilište u Zagrebu, "Srce | Sveučilišni računski centar Sveučilišta u Zagrebu.” https://www.srce.unizg.hr/ (accessed May 10, 2020).

[36] S. Nidogon Višnjić and K. Pažur Aničić, "Attitutes of students and employers to the use of student centers 'IT services," 2020. 